\title{
Challenges in the pharmacotherapy of urogenital disorders
}

\author{
Martin C. Michel* \\ Department of Pharmacology and Pharmacotherapy, Academic Medical Center, Amsterdam, Netherlands \\ *Correspondence: m.c.michel@amc.nl
}

\begin{abstract}
Although some urogenital drugs such as tamsulosin or tolterodine have reached blockbuster status, the pharmacotherapy of urogenital disorders has been lagging behind many other therapeutic areas for a long time. Malformations and trauma of the urogenital tract are a clear domain of surgery, and malignant urogenital disease has more in common with malignancies of other tissues than with other urogenital disorders; hence, both groups of disorders are not topical for this journal. However, a large number of functional disorders of the urogenital tract exist. These include lower urinary tract symptoms suggestive of benign prostatic hyperplasia (LUTS/BPH), the overactive bladder symptom complex (OAB), stress urinary incontinence, erectile dysfunction (ED), ejaculation disorders, preterm labor, and ureteral stone disease. Many of these conditions are highly prevalent in the general population. Despite being largely functional disorders, their treatment often was based on surgical approach (e.g., LUTS/BPH) or limited to conservative management.
\end{abstract}

\section{INSUFFICIENT PATHOPHYSIOLOGICAL UNDERSTANDING}

The physiology and pathophysiology of the urogenital system is more complex than often assumed. For example, $\alpha_{1}$-adrenoceptor antagonists for the treatment of LUTS/BPH have long been assumed to primarily work by relaxing prostate smooth muscle, but meanwhile it has become clear that this mechanism at best can explain part of their therapeutic effects (Michel, 2010). Similarly, muscarinic receptor antagonists have long been thought to act by relaxing bladder detrusor smooth muscle, but we now realize that effects on urothelial mediator release and/ or afferent nerves may also contribute to their therapeutic effects (Yamaguchi, 2010). Moreover, the function of urogenital tissues is often controlled by the central nervous system (Birder et al., 2010) but this is less well understood than peripheral control, particularly at the smooth muscle level. A better understanding of the physiology and pathophysiology of the urogenital system is urgently needed to provide the basis for a more effective and/or better tolerated pharmacotherapy of related disorders.

\section{STRONG PLACEBO EFFECTS}

The last two decades have witnessed extra-ordinary progress in the treatment of many functional urogenital disorders. The primary treatment of LUTS/BPH has largely shifted from surgical to medical treatments, the medical treatment of $\mathrm{OAB}$ has experienced major progress in tolerability, and effective oral treatment of ED became available. Nevertheless, many therapeutic challenges remain, e.g., the use of $\alpha_{1}$-adrenoceptor antagonists for the treatment of LUTS/BPH (Milani and Djavan, 2005) or that of muscarinic receptor antagonists for the treatment of OAB (Chapple et al., 2008) has only limited efficacy relative to placebo. Actually, the relative efficacy of placebo treatment in some urogenital disorders is surprisingly high but not well understood.

\section{RISK-BENEFIT RATIOS IN VULNERABLE TARGET POPULATIONS}

Fortunately, many urogenital disorders cause limited secondary morbidity or even mortality. Nevertheless, they often cause major adverse effects on quality of life, interestingly in several cases not only for the afflicted patient but also for their partners. Many urogenital disorders affect largely elderly patients who are characterized by frequent comorbidities and comedications. These can cause disease-associated vulnerabilities but also risks due to drugdrug interactions. While preterm labor affects a much younger patient group, the vulnerability of the unborn child also raises specific safety concerns. Thus, the combination of non-life-threatening diseases on the one hand and of highly vulnerable patient populations on the other hand, creates a need for particularly safe drugs. How this risk-benefit ratio should be defined remains under discussion as highlighted by the fact that drugs such as duloxetine for the treatment of stress urinary incontinence (Michel and Oelke, 2005) and dapoxetine for the treatment of premature ejaculation (McCarty and Dinsmore, 2010) were registered by European but not US authorities.

\section{LOCAL ACCESSIBILITY}

Several urogenital tissues are in principle accessible to local, i.e., trans-urethral treatments as exemplified by the use of botulinum A toxin (Karsenty et al., 2008). Alternatively, drugs which are excreted in active form via the kidneys may also yield higher exposure in urogenital tissues than systemically. However, such pharmacokinetic peculiarities of the urogenital tract have only been insufficiently explored.

\section{CONCLUSION}

All of the above factors create challenges for the future pharmacotherapy of urogenital disorders, and it is hoped that this journal will contribute to meeting those challenges.

\section{REFERENCES}

Birder, L., De Groat, W., Mills, I., Morrison, J., Thor, K., and Drake, M. (2010). Neural control of the lower urinary tract: peripheral and spinal mechanisms. Neurourol. Urodyn. 29, 128-139.

Chapple, C. R., Khullar, V., Gabriel, Z., Muston, D., Biton, C. E., and Weinstein, D. (2008). The effects of antimuscarinic treatments in overactive bladder: an update of a systematic review and meta-analysis. Eur. Urol. 54, 543-562.

Karsenty, G., Denys, P., Amarenco, G., De Seze, M., Game, X., Haab, F., Kerdraon, J., Perrouin-Verbe, B., Ruffion, A., Saussine, C., Soler, J.-M., Schurch, B., and Chartier-Kastler, E. (2008). Botulinum Toxin A $\left(\right.$ Botox $\left.^{\oplus}\right)$ intradetrusor injections in adults with neurogenic detrusor overactivity/neurogenic overactive bladder: a systematic literature review. Eur. Urol. 53, 275-287. 
Mccarty, E. J., and Dinsmore,W.W. (2010). Premature ejaculation: treatment Update. Int. J. STD AIDS 21, 77-81.

Michel, M. C. (2010). The forefront of novel therapeutic agents based on the pathophysiology of lower urinary tract dysfunction: $\alpha$-blockers in the treatment of male voiding dysfunction - how do they work and why do they differ in tolerability? J. Pharmacol. Sci. 112, 151-157.

Michel, M. C., and Oelke, M. (2005). Duloxetine in the treatment of stress urinary incontinence. Womens Health 1, 345-358.
Milani, S., and Djavan, B. (2005). Lower urinary tract symptoms suggestive of benign prostatic hyperplasia: latest updated on $\alpha_{1}$-adrenoceptor antagonists. BJU Int. 95(Suppl. 4), 29-36.

Yamaguchi, O. (2010). Antimuscarinics and overactive bladder: other mechanism of action. Neurourol. Urodyn. 29, 112-115.

Received: 17 August 2010; accepted: 25 August 2010; published online: 16 September 2010.
Citation: Michel MC (2010) Challenges in the pharmacotherapy of urogenital disorders. Front. Pharmacol. 1:117 doi:10.3389/fphar.2010.00117

This article was submitted to Frontiers in Cardiovascular and Smooth Muscle Pharmacology, a specialty of Frontiers in Pharmacology.

Copyright (C) 2010 Michel. This is an open-access article subject to an exclusive license agreement between the authors and the Frontiers Research Foundation, which permits unrestricted use, distribution, and reproduction in any medium, provided the original authors and source are credited. 